charts for a hemisphere, if not for the whole world.

The great importance of weather in aviation necessitates close relations between meteorological services and the authorities in charge of air lines. To meet this need, the conference at Warsaw formed a new commission, the purpose of which is to keep in close touch with the requirements of aviation, and to maintain and develop as required the meteorological organisation necessary for this purpose.

Another aspect of synoptic meteorology to which reference must be made is the construction of detailed daily charts of the northern hemisphere, now being prepared by the Deutsche Seewarte with international co-operation for the whole period of the Polar Year 1932-33. As reported by the Polar Year Commission, the preparation of these charts is progressing, though difficulty is being experienced in obtaining data for some of the more remote parts of the northern hemisphere. When completed, these charts will be of the greatest value for studies in dynamical meteorology.

The tendency towards internationalisation has appeared also in the domain of climatology, in the form of an international 'alphabet' for the headings of columns. Thus the column, for example, for 'pressure' in a climatological table should bear the letter $P$, no matter what country issues the table. The Climatological Commission has also devised a standard form of table for the guidance of meteorological institutes. Months are designated I-XII, but both in climatology and in agricultural meteorology the need has been felt for the use of a unit of time shorter than a month and there has been great dis. cussion of the relative advantages of the 5-day period, or pentad, and the week, with the result that both units have received international approval.

The Commission for Terrestrial Magnetism and Atmospheric Electricity was occupied mainly with questions of detail. Among the resolutions were also appreciations of the action of the British Admiralty in deciding on the construction of a non-magnetic ship specially designed to carry on the researches formerly made on the ill-fated Carnegie, and of the Canadian authorities in transforming the temporary geophysical station erected at Chesterfield Inlet for the Polar Year into a permanent station.

The report of the Commission for Bibliography, which was unanimously adopted by the conference, presented a new plan of classification for meteorological literature, affiliated to the decimal classification of the International Institute of Bibliography, but thoroughly revised. This classification has been studied and discussed for several years, and its completion will greatly facilitate bibliographical work in meteorology.

The work of an international conference does not end with the formal debates and resolutions; there remain many problems which can only be resolved by private discussion among the members. The value of the Warsaw conference was greatly increased by the presence of delegates from all parts of the world. Africa was especially well represented, and the practical problems of organisation in that difficult continent were fully explored.

On Sunday, September 8, an all-day excursion was made to the new aerological and radiometeorological observatory at Jablonna, which owes its inception to Dr. Lugeon, and which promises to be of as great importance in studies of the ionosphere in Poland as is the station at Slough, in England. On the evening before the final meeting, H.E. the Minister of Communications entertained members and their wives to a State banquet, where all speakers reflected the spirit of optimism prevailing in meteorology to-day, which was the keynote of the whole conference. After the meeting, many of the delegates proceeded to Cracow and the Tatra Mountains on an excursion which was admirably organised and provided an experience not readily to be forgotten.

\title{
Biochemistry in Relation to Therapeutics
}

GIR FREDERICK GOWLAND HOPKINS delivered the inaugural sessional address at the opening of the ninety-fourth Session of the College of the Pharmaceutical Society on Wednesday, October 2. His address included a wide survey of the needs of pharmacy to-day and of the educational means for satisfying them, and led him to examine a problem as old as education itself, the problem of how far vocational training is compatible with true education in which a subject is studied for its own sake as an intellectual exercise. It has often been said that science can only be taught properly when it is taught as pure science without reference to its applications. This claim is justified to the extent that vocational needs must not make the teaching of science so one-sided that the student risks missing the intellectual stimulus which the great generalisations of science provide.

Teachers of applied scientific subjects will be grateful to the president of the Royal Society for his declaration that the skilful teacher of students whose ultimate aim is to apply science in practice, can illustrate general principles adequately while selecting facts and aspects which have a permanent vocational value. Indeed, for the encouragement of the average student, it is important that the reality of this permanent value should be part of his faith. Without it he can never be an enthusiast for his calling. The preference for vocational training may well be based on the Anglo-Saxon preference for action rather than thought and for practice rather than theory, but it is an attitude of mind having in it the seeds of certain dangers. Indeed, a distrust of theory has sometimes kept Great Britain from being in the van of intellectual and not less of commercial progress : "It was because it had become really scientific that the medical knowledge of another country received for a long period and up to the time of the War the greatest respect in the world and it was because its chemists were so fully trained in theory that the same country obtained among other similar advantages a long lead in the production of synthetic drugs which rightly or wrongly brought it enormous profits".

On the same occasion Sir Frederick Gowland Hopkins took occasion to review the present state of biochemistry; in particular, in its relation to 
therapeutics. As he pointed out, while the structure of a drug administered as a medicine may be known, very little has been known about the nature of the events in the tissues of the body which are affected by the drug. The pharmacologist relies upon the obvious and visible reaction of the body as a whole to the drug when administered, or at least, of the reaction of a specific organ as a whole. His observations throw little light upon the precise and intimate mechanism of the drug's action. This is the province of biochemistry, and modern biochemistry is fast acquiring methods which enable it to follow the progress of the invisible molecular events which occur in the tissues while they are living.

Biochemistry should in the future be able to describe in detail the numerous chemical reactions which proceed in ordered sequence in every living tissue cell. The great majority of drugs act by intruding among these chemical reactions and by modifying their course or by entering relations with the enzymes which catalyse these reactions. When we know into what kind of reaction and at what stage in its progress a given kind of molecule intrudes, or when we know exactly the chemical nature of the enzyme with which, owing to mutual structural affinities, it makes sufficient contact, then we shall be in a better position for understanding just why the details of its molecular structure confer upon each drug a particular physiological activity. Biochemical investigation of the relationships of the vitamins and hormones has led to the view that it is nearly, if not quite, justifiable to look upon a vitamin as a hormone which the body cannot make for itself, or on a hormone as a vitamin which it does make for itself.

\section{Educational Topics and Events}

ST. ANDrews.-Mrs. Low of Blebo has given $£ 1,000$ to the University for the purpose of founding in memory of her son, the late Capt. W. A. Low, a Gold Medal and prize to be awarded annually to the student adjudged to have had the most distinguished course among those graduating in the year as M.B.,Ch.B. The foundation will be named "The Captain W. A. Low Memorial Prize".

The Court has appointed Dr. James A. Macdonald to be a lecturer in botany in the United College.

Dr. James F. Murray, lecturer in bacteriology in the Medical School, Dundee, having resigned that post, the Court has appointed Dr. Alexander B. Stewart, presently assistant in the Department, to the vacant lectureship.

In the old Parliament Hall, St. Andrews, on Friday, October 4, Dr. E. T. Copson was inducted to the chair of mathematies and Dr. R. C. Garry to the chair of physiology, both in University College, Dundee.

Among the university extension and tutorial classes arranged by the University Extension Com. mittee of the University of London is a series of lectures on the human mind to be delivered by Prof. Cyril Burt in the City L.C.C. Literary Institute beginning on January 15, and a series on recent discoveries in psychology by Dr. C. E. Allen being given in the lecture hall of the public library, Croydon, which began on October 9 . Other lectures on psychology are being delivered by Mr. E. Miller, Mrs. G. R. Blanco-White and Mr. C. E. M. Joad, at Morley
College, and the Rev. F. E. England in Whitefield's Central Mission. Apart from these courses in psychology, the only other series of lectures of scientific interest is that by Prof. W. B. Brierley on the biological sciences and modern problems at Gresham College, which began on October 2. A complete list of the lectures can be obtained from the University Extension Registrar, University of London, South Kensington, S.W.7.

THE appeal for new buildings for Birkbeck College (University of London) was launched at a meeting arranged by Lord and Lady Luke at 29 Portman Square on October 2. Lord Luke, chairman of the Appeal Committee, announced that His Royal Highness the Duke of York has consented to accept the presidency of the College and will be present with the Duchess at a meeting at the Mansion House on November 7 when the Lord Mayor and Mr. Ramsay Mac. donald, both old students of the College, will speak on the needs of Birkbeck. Mr. Hichens, chairman of the Governors, referred to the grant by the University of London of space for the new buildings on the University site in Bloomsbury, and Dame Helen Gwynne-Vaughan spoke of the good work of Birkbeck students. As is well known, Birkbeck College is a school of the University of London for evening and part-time students who are prevented by their employment from attendance at a college during the day. In the Science Departments, an increasing number of students come from large research laboratories under the auspices of the Department for Scientific and Industrial Research or of private firms. A special feature of the College is the strength of the postgraduate work; each year sees the publication of numerous contributions to knowledge resulting from the work of staff and students. Opportunity for investigation is given to a large number of capable men and women.

IN university circles in the United States there is widespread anxiety as to the curtailment of academic freedom. Leaders in the learned world denounce the 'brutal tyrannies' under which in more than one foreign country the expression of opinions and even the dissemination and discussion of information in universities have been stifled. Of three graduation addresses by the presidents of Harvard, Yale and Princeton, respectively, published in School and Society of July 13, two contain such denunciations, and one disparages the extravagant faith, so common in this age, in the efficacy of idealised social systems such as Communism and Fascism as devices for lifting humanity by its own bootstraps. A week earlier, the well-known chancellor (S. P. Capen) of another university held forth on a similar occasion on "The Obligation of the University to American Democracy". $\mathrm{He}$ contrasted the functions of universities in countries such as Italy, Germany and Russia, where there are dictatorships, and in democratic countries. In the former these functions have been simplified and the universities have become, in so far as they concern themselves with the social sciences, organs of propaganda. In the latter, in so far as they are true to democratic principles, the method of the propagandist is abhorrent to them. Nevertheless, in the United States alone among democratic countries, the procedure of universities in this respect is, we are told, challenged and they are constantly being attacked for "teaching socialism or pacifism or atheism or communism, or all of them together". 